\title{
THE WOMEN'S GLOBAL LEADERSHIP FORUM: ENHANCING ONE COMPANY'S GLOBAL LEADERSHIP CAPABILITY
}

\author{
Nancy J. Adler, Laura W. Brody, and Joyce S. Osland
}

\begin{abstract}
Will women become leaders in the increasingly global world of the twenty-first century? According to many Chief Executive Officers (CEOs), promoting the best people-whether male or female-into senior leadership positions is a strategic necessity if their companies are to succeed, let alone prosper. This article describes the commitment that one major multinational's CEO made to moving women from around the world into the most senior leadership positions. It describes an organizational development process, led by the CEO that included a targeted survey of both male and female executives, convening a 4 1/2-day Global Leadership Forum, and actively changing the organization based on recommendations generated at the Forum. (C) 2000 John Wiley \& Sons, Inc.
\end{abstract}

\section{Introduction}

The best reason for believing that more women will be in charge before long is that in a ferociously competitive global economy, no company can afford to waste valuable brainpower simply because it's wearing a skirt.

—A. Fisher, Fortune Magazine, 1992

"For all practical purposes, all business today is global" (Mitroff, 1987, p.ix). Over the past 50 years, world output grew by an impressive 600 percent, and world trade grew by an even more impressive 1,500 percent (Hill, 1998). In just the past decade, the annual flow of foreign direct investment worldwide "increased nearly sixfold to $\$ 315$ billion, a growth rate that is more than twice as fast as the growth rate in world trade" (Hill, 1998, p.10). As the 21st Century Report revealed, more than two-thirds of the world's CEOs view foreign competition as a key factor in future business success (Hambrick, Korn, Fredrickson, \& Ferry, 1989). Not surprisingly, the same CEOs expect to generate employment and revenues increasingly from outside their company's home country (Hambrick et al., 1989). As management scholar Ian Mitroff (1987) aptly observes, "Those individual businesses, firms, industries, and whole societies that clearly understand the new rules of doing business in a world economy will prosper; those that do not will perish." (p.ix) "Global competition ... [is forcing] executives to recognize that if they and their organizations are to survive, let alone prosper, they will have to learn to manage and to think very differently" (Mitroff, 1987, p.x). Are senior executives prepared to think and to manage very differently?

Although all too rarely recognized as such, global leadership is not the same as
As the $21 \mathrm{st}$ Century Report revealed, more than two-thirds of the world's CEOs view foreign competition as a key factor in future business success. 
Bestfoods' leadership is as global as the company's operations. domestic leadership (see Adler 1997b; Bartlett \& Ghoshal, 1989; Dorfman, 1996). As society moves into the twenty-first century, the domain of influence of leadership is rapidly shifting from the circumscribed geographies of the past to the globally encompassing geographies of the present and future; that is, leadership is shifting from focusing on a part of the world-most commonly a nation or domestic economy-to focusing on the whole world. Competition is forcing companies that formerly succeeded by using either domestic or multidomestic strategies to replace such approaches with integrated cross-cultural interactive global strategies. Historically, global leadership "that goes beyond the nation-state and seeks to address all human beings [has been] . . . the most important, but rarest and most elusive, variety of leadership" (Gardner, 1995, p.20). Today the "rare" is becoming a necessity.

\section{Women: Increasingly Important as Global Leaders}

Will women become leaders in this increasingly global world of the twenty-first century? Based on history, many believe the answer to be no. Women today hold less than 3 percent of the most senior management positions in major corporations in the United States (Wellington, 1996, as reported in Himelstein, 1996) and less than 2 percent of all senior management positions in Europe (Dwyer, Johnston, \& Lowry, 1996). In countries such as Italy, the proportion of women executives falls to a paltry 0.1 percent (Dwyer et al., 1996; International Labor Office, 1997).

Can companies - and countries - afford to continue historic patterns of male dominated leadership? As global competition intensifies, the opportunity cost of such patterns escalates. Many believe that companies can no longer afford to disregard potential talent simply because it's wearing a skirt (Fisher, 1992). As Harvard Professor Rosabeth Moss Kanter (1994) suggests, in a global economy, "Meritocracy-letting talent rise to the top regardless of where it is found and whether it is male or female-is essential to business success" (p.89).

Careful observation indicates that leading countries and companies are already begin- ning to move away from their traditional patterns. For example, of the 48 women who have served in their country's highest political leadership position-as president or prime minister of the nation-over 60 percent have come into office in just the last decade. ${ }^{1}$ Similarly, among women CEOs leading major companies today, almost all are the first woman whom their particular company has ever selected. ${ }^{2}$ The pattern is changing. The only questions remaining are: Which companies will lead and which will fall behind? Which strategies will prove most effective in moving women into the most senior leadership positions? The following section describes one company's experience in creating significant organizational change.

\section{One Company's Odyssey: Global Women Leaders at Bestfoods}

Bestfoods, formerly CPC International Inc., is among the largest U.S. branded food companies, with 1997 annual sales of \$8.4 billion. Headquartered in Englewood Cliffs, New Jersey, Bestfoods is one of the nation's most international food companies, with operations in more than 60 countries and products marketed in 110 countries. Although headquartered in the United States, the company earns 60 percent of its revenues from non-U.S. sources. The company projects future growth to continue to come primarily from outside the mature markets of North America and Western Europe. Africa, Asia, Eastern Europe, the Middle East, Latin America, and the countries of the former Soviet Union are projected to lead increases in twenty-first century revenue.

Most widely recognized among Bestfoods' products are: Hellmann's and BestFoods mayonnaise and dressings; Mazola corn oil and margarine; Skippy peanut butter; Knorr soups, sauces, and bouillons; Entenmann's sweet baked products; Thomas' English muffins; Arnold, Brownberry, Freihofer's and Oroweat breads; Boboli pizza crusts; Mueller's pasta; and Karo syrup. Bestfoods' global Knorr brand comprises one of the world's most extensive lines of products.

Bestfoods' leadership is as global as the company's operations. Currently, almost 
half of the 20 corporate officers come from outside of the United States, with eight nationalities represented among them. Similarly, half of the members of the Board of Directors are not from the traditional group leading most major corporations-white men. On a Board of fourteen, five passports are represented. Another two of the current and former CEOs sitting on Bestfoods' Board are women. Of Bestfoods' 44,000 employees, two-thirds currently work outside of the United States.

Consumer foods, not unlike many other industries, has become an increasingly competitive industry in which only the companies with top brands and top talent will survive. Whereas many consumer foods companies used to be able to operate as loose confederations of fairly autonomous country operations, global competition is now forcing all members of the industry to more closely coordinate their operations worldwide. As is typical of the industry, Bestfoods, which for years employed a highly successful multidomestic strategy, now finds itself coordinating globally to an extent heretofore found unnecessary.

To succeed in such an environment, Bestfoods increasingly needs to attract and retain the best talent available worldwide. Such global talent needs to operate effectively at both the global and local levels. For any company to succeed, targeted talent should, and increasingly does, include both women and men.

With women making more than 80 percent of purchasing decisions for Bestfoods' products, the leadership of the company believes that it will not survive if it fails to understand women's needs. Without women represented in both the most senior executive positions as well as broadly throughout management, no company in this industry can hope to sustain a competitive advantage. Bestfoods is no exception.

There is no question that Dick Shoemate, Bestfoods' CEO, fully understands this competitive necessity and its implications for the company's future. Under his leadership, Bestfoods' commitment to retain and to develop the most highly talented women and men from around the world has been made explicit:
We believe that one of Bestfoods' unique competitive strengths is a management team that delivers outstanding performance in the local marketplace and also works together to build the "Best International Food Company in the World." . . . We actively seek to identify and to develop high performing Bestfoods' managers throughout the company, including men and women from all countries and ethnic backgrounds. ${ }^{3}$

Moreover, the CEO recognizes that words are not enough to institute the changes necessary for twenty-first century success.

By 1997, 14 percent of the members of the Board of Directors, 16 percent of the corporate officers, and 13 percent of directors and vice-presidents were women. Compared to many companies, these numbers are excellent. Mr. Shoemate, however, did not see them as sufficient to support the future he envisioned for Bestfoods. The CEO therefore decided to send a clear signal to the organization that he wanted to make rapid progress on including more women in senior management and leadership.

Of the many ways in which he could send his message, the CEO purposely chose to use the same approach that he uses both to address the company's most important strategic issues and to develop its most senior leadership. Together with the Corporate Strategy Council ${ }^{4}$, he chose to convene a Women's Global Leadership Forum-an off-site meeting at the Arrowwood Conference Center with participants from around the world. Because Bestfoods uses Arrowwood for many of its important meetings and leadership development programs, choosing this location for the Women's Global Leadership Forum symbolically communicated the importance that the company's senior leadership was attaching to the meeting.

The CEO further communicated the importance and urgency of the issue by announcing that Bestfoods' first-ever Women's Global Leadership Forum would be held within the next 90 days. The primary difference between the Forum and other executive off-site meetings was that this time the participants would be exclusively women, and the issue addressed would be how to assure
The CEO therefore decided to send a clear signal to the organization that he wanted to make rapid progress on including more women in senior management and leadership. 
Responding to the nomination process, one country manager revealed that he was pleasantly surprised to discover that there were more high potential women in his affiliate than he had previously thought.
Bestfoods' future competitiveness by developing and retaining the company's most talented women. By contrast, most prior senior management meetings and retreats, similar to those held by the majority of companies, had most often included predominantly men, and sometimes had only men attending.

As announced, the planned Women's Global Leadership Forum would be held for 4 1/2 days under the leadership of Laura Brody, Director of Diversity and Development for Bestfoods. Invitations would be extended to 50 of the most talented, senior, and respected women from each region around the world, representing 25 countries and virtually every function in the company. In addition, both women members of the Board of Directors, all members of the Corporate Strategy Council, and the majority of other corporate officers would be invited to participate in the opening of the Forum as well as selected sessions. The CEO's goals for his company's first Women's Global Leadership Forum were to:

- Increase the global competitiveness of Bestfoods

- Develop the global leadership skills of Bestfoods' most highly talented and senior women

- Create an internal network among Bestfoods' women leaders to facilitate their global effectiveness

- Develop both global and local recommendations for enhancing Bestfoods' ability to support the career advancement and success of an increasing number of highly talented and senior women

\section{Creating an Environment for Change: The Process Leading Up to the Forum}

Whereas the Forum was to be a focal point, it was embedded in a larger process of organizational change and development. The initial step in the process was focused on identifying the full range of the company's highly talented women and providing visibility for them both as potential invitees to the Forum and, more importantly, as part of the talent pool for the company's future leadership. To create a comprehensive list of senior and high potential women, Laura Brody solicited nominations from all division presidents. She personally reviewed all lists of high potentials and considered all recipients of the company's incentive and retention programs, including all women who had received incentive bonuses, restricted-stock-awards, and stock-options.

After Brody had created a list of potential invitees, the CEO sent a letter to the six members of the Corporate Strategy Council describing the Forum and requesting that they rank order their nominees. Similar to the process used by the company for its senior management programs at Arrowwood, spaces at the Women's Global Leadership Forum were allocated according to the relative size of each division, which ensured a balanced representation from around the world. In making the selection, two key design parameters were followed; first, that the Forum be capped at $\mathbf{5 0}$ participants and second, that a minimum of half of the participants come from outside the United States.

The Corporate Strategy Council expressed some concern about the potential reaction from various parts of the organization to holding a women's forum. The highly visible and vocal support of Dick Bergeman, the senior vice president of human resources, along with the support of the human resource directors in Europe, Asia, the United States, and Latin America, helped to diffuse some of the potentially negative reactions this controversial, yet innovative program could cause. The immediate response to the announcement was extremely favorable. Every division requested additional spaces for women from their area. In response to their requests, the total number of potential participants was increased to 60 . The additional ten were invited as both participants and small group facilitators. Responding to the nomination process, one country manager revealed that he was pleasantly surprised to discover that there were more high potential women, albeit quite junior, in his affiliate than he had previously thought. Many women in the company responded particularly positively to hearing that Bestfoods would be holding a Women's Global Leadership Forum. 
In the ensuing weeks, reactions varied among both men and women. Some men were very positive and believed that such a forum was long overdue. Others expressed skepticism. While still others were quite negative, believing that the very process discriminated against men. Some men informally referred to the upcoming Forum as "a coffee klatch" and "the girls' knitting club", and cautioned that it could only turn into "a bitch session".

The women's reactions also varied, with some positive and others more cautious or negative. Many women were delighted, not only that Bestfoods was holding the Forum, but also that the CEO had invited them to such a groundbreaking event. One senior woman sent a letter to Dick Shoemate expressing her amazement, "I never thought I would live to see the day that this company, or any company, would hold such a Forum. ... Congratulations! I am 100 percent with you”. Other women expressed concern that in singling them out as women, the company was not recognizing their business accomplishments. As one European participant commented, "I am happy to attend the Forum if I'm being invited because of my business acumen as one of the top 100 people in this company; not simply because I am 'a girl'." Other women expressed fear concerning men's potentially negative reactions toward them as well as toward other women.

\section{Gathering Expertise: Going Beyond What We Know Well}

Because the Forum was a first, the company sought external expertise. Brody contacted a variety of consultants who were experts in organizational development and leadership development, including those with particular expertise on women. None of her initial contacts had the range of skills necessary to help design both the overall organizational change effort as well as the Forum itself. Some had extensive expertise in working with women and the movement of women up through the ranks of major corporations, but failed to have a global perspective. Their knowledge base and experience were almost entirely limited to the United States. Others had extensive global experience but had never considered the unique role of women in the leadership of global corporations.

Based on Brody's familiarity with Adler's work on global management, women expatriate managers, and global women leaders, Brody contacted Nancy Adler at McGill University's Faculty of Management in Montreal. Following in-depth discussions about all aspects of the project, both Adler and Brody were committed to working with each other to help create something new, something that few major multinational companies had ever attempted. Later, Dr. Joyce Osland was added to the team due to her experience developing women leaders in Latin America (see Osland, Snyder, \& Hunter, 1998).

\section{Gathering Expertise: Learning What the Organization Already Knew}

When trying to understand women and power, myths abound. To anchor the Women's Global Leadership Forum and organizational change process in reality, a survey was designed. The survey aimed at differentiating what was true from what people thought to be true about women's and men's career strategies, as well as documenting the obstacles each group faces in achieving success. In particular, the survey was designed to address many of the company's most important concerns about developing and retaining senior women. ${ }^{5}$

Beyond generating results, the survey was also used as a way to involve Bestfoods' most senior men and women in the questions that the company needed to address as well as to build their support for implementing the recommendations that the Forum would generate. The confidential survey was sent to all 20 corporate officers, the next 125 most senior executives of whom 92 percent are men, and the 60 women who had been nominated to attend the Forum. Seventy percent of both the men and women returned the survey.

The survey itself was extensive, containing ten sections, each with a minimum of fifteen questions. It documented the benefits to the company, as perceived by women and men, of having more women in leadership positions. The survey focused on the actual strategies that individuals had used to advance their own 
... more than ten times as many women as men believed that developing a style that men are comfortable with is critical to women's career success. careers, along with the barriers that each had faced. It solicited recommendations from women and men on what the company and individual women should do to increase the number of women in senior management positions. While identifying some similarities, the survey revealed many highly significant differences between women's and men's perceptions of reality. The issues, concerns, and gaps identified are in no way unique to Bestfoods, but rather echo a more general pattern that is well documented in recent research (Ragins, Townsend, \& Mattis, 1998).

\section{Moving Ahead: Career Advancement Strategies}

Women and men agreed on the three most important strategies for women's career success at Bestfoods:

- Consistently exceeding performance expectations

- Gaining line management experience

- Seeking difficult and high visibility assignments

Following these top three strategies, however, women and men saw the world quite differently. For example, more than ten times as many women as men believed that developing a style that men are comfortable with is critical to women's career success. ${ }^{6}$ Men, by contrast, believed that such a make men comfortable approach was the next to the least important strategy women could follow. Women and men also disagreed on the importance of having a mentor. Almost twice as many women as men believed that women needed to develop a relationship with an influential mentor in order to succeed. ${ }^{7}$

Whereas women consistently included various aspects of relationship building in their understanding of the requirements for senior management, men tended to focus more narrowly on task-related considerations. For example, in contrast to the develop a style that men are comfortable with and develop a relationship with an influential mentor recommendations of the women, three times as many men as women stressed the importance of gaining international experience. If things did not work out well for them, none of the men reported considering changing companies to get ahead, while a striking 14 percent of the women stated that they would consider such an idea.

When asked what the company should do to facilitate women's career advancement, women and men again agreed on the most important strategies:

- Give women more assignments that include managing people.

- Include more women on divisional and global strategic taskforces.

- Include more women in the Arrowwood Senior Management Development Program.

- Hold managers more strictly accountable for identifying, developing, and advancing high potential women across all management levels.

- Ensure that succession plans include a higher proportion of women.

The women, however, consistently rated the importance of these and other company initiatives more highly than did men. For example, more than three-quarters of the women, but only half of the men, thought that it was important for the company to include women on divisional and global strategic taskforces. Similarly, more than twice as many women as men reported that it was important for the company to send women to external development programs. Likewise, 60 percent of the women, but only 43 percent of the men, believed that it was critical to hold managers more accountable for developing and advancing high potential women-with three times as many women as men reporting that it was extremely important to use numerical targets. In addition, twice as many women as men thought that it was critically important to have flexible work policies.

Overall, women understand that it will take both corporate and individual strategies for women to move ahead. By contrast, men tend to deemphasize what the company can do to foster women's development and advancement, while stressing what the women should do for themselves. Almost two-thirds 
of the men, but less than half of the women, explicitly stated that it was up to women to change to fit into the company's current corporate culture.

Failing to Move Ahead: Barriers to Career Advancement

Women and men agree on what are not barriers. Almost 90 percent see women as equally well prepared for senior leadership positions as their male counterparts and as having what it takes to get to the top. Additionally, more than three-quarters of both men and women agree that women exhibit an effective leadership style, along with having the technical and educational credentials needed for success in senior management.

A very interesting pattern emerges, however, from the similarities and differences among men's and women's perceptions of the most critical barriers to women's career success. Women agree with the top five barriers identified by men:

- Women's lack of general management and line experience

- Women not having been in the pipeline long enough

- Women's lack of mobility to take international assignments

- Limitations imposed by the husband's career

- Women's unwillingness to sacrifice personal and family life to follow a traditional corporate career path

The women reported an additional set of barriers that they experience as being even more critical to their advancement than the top five barriers that men identified. Approximately three-quarters of the women, yet only a third of the men, considered removing the following barriers to be a necessary and crucial first step before women could progress into senior-level positions:

- Senior men being uncomfortable with ambitious women

- Senior men's negative stereotyping and preconceptions of women

- Senior men's difficulty in reporting to a woman
These additional barriers facing women appear to be largely invisible to most men. It is clear that women at Bestfoods face more barriers to their career advancement than do men, but, more importantly, the types of barriers they face differ. All of the barriers that men recognize are framed as primarily women's own responsibility (e.g., women's lack of mobility, line experience, and time in the pipeline). Women do not disagree with the barriers identified by men; however, they see the most important barriers to their career progress as being the negative perceptions held by many men (e.g., men being uncomfortable with ambitious women, negatively stereotyping women, and being uncomfortable reporting to a woman).

Given these differences in perception, the first step in any organizational change effort must be to help both men and women understand each other's reality. Based on the survey, for Bestfoods to succeed in its change effort, both men and women need to change. The organizational "problem" is neither singularly women's behavior nor men's attitudes; rather, it is for both to learn to see the organization and what it means to work together in new ways. The survey results thus reinforced the need for the Forum as a place where both women and men could better understand each other's reality and where reality-based, rather than myth-based, recommendations could be generated.

\section{The Women's Global Leadership Forum: A Catalyst for Change}

The Women's Global Leadership Forum convened in July 1998 on a Sunday evening to begin meetings that would last through the following Thursday. The 55 participants came from 25 countries and represented every function within the company. ${ }^{8}$ The average participant was 41 years old, married, and had at least one teenage child; however, the diversity among participants was significant. There was a 29-year gap between the oldest and the youngest participant, and participants' families ranged from those with grown-up children, to those with toddlers, to single women without any children. The average participant had at least 15 years of professional experience and
Additionally, more than threequarters of both men and women agree that women exhibit an effective leadership style, along with having the technical and educational credentials needed for success in senior management. 
One of the CEO's core goals for the Forum was to develop the global leadership skills of Bestfoods' most highly talented and senior women.
10 years of experience at Bestfoods; however, one woman had 26 years of experience while another had only joined Bestfoods within the past year. The participants were highly educated. Almost all had a bachelor's degree, with almost half having a master's degree or doctorate. The typical participant spoke at least two languages, with some Europeans speaking as many as five languages. The majority of Americans were monolingual. A quarter of the women had worked outside of their home country - some having lived and worked in as many as five countries. Fewer participants from the United States than elsewhere had benefited from such international experience.

While at the Forum, attendees participated in plenary sessions involving all of the women, many of the company's senior male executives, and a few board members. They also deliberated in global teams - small groups that included women from around the world. Facilitators for these global teams, who themselves represented a wide range of countries, received training in a half-day, pre-Forum workshop to enhance their cross-cultural leadership, team building, communication, and facilitation skills.

The Forum itself had the three-fold objective of developing:

1. Individual participants' global leadership skills

2. A network of women leaders

3. The overall organization

As highlighted in Table I, the series of activities planned for the 4 1/2-day Forum was designed to further all three objectives, with some activities more focused at the individual level, some at the group or network level, and some at the organizational level.

\section{Developing the Individual: Enhancing Global Leadership Skills}

One of the CEO's core goals for the Forum was to develop the global leadership skills of Bestfoods' most highly talented and senior women. Global leaders, unlike their domestic counterparts, must be able to articulate a globally encompassing vision and to communicate that vision to people around the world in ways that inspire them to work together to achieve individual, organizational, and societal goals (Adler, 1997b; Bartlett, \& Ghoshal, 1989; Hamel \& Prahalad, 1986). Woven throughout the Forum were lectures, discussions, exercises, and team meetings designed to enhance the global leadership skills of participants - and therefore, of the company's highest ranked and highest potential women. The activities focused on developing a full range of fundamental types of power, including power to, power with, and power within, along with the more traditional hierarchical power over.

Power to. To enhance participants' skills at creating a globally encompassing visionthat is, to enhance their power to skills-they were asked, prior to the Forum, to prepare a vision statement expressing their ideal professional and personal accomplishments. This statement-expressing what each woman wanted to accomplish and how she planned to accomplish it-was to be written in the form of a hypothetical CNN documentary scheduled to be televised worldwide. At the Forum, each woman presented her visiondocumentary and received feedback on the content of her vision and on her delivery from colleagues from around the world. Would the message be meaningful to Latin Americans? Would it inspire Europeans? Would it motivate Asians? Would North Americans consider it worthwhile?

Power with. In a global context, enhancing power with skills means increasing leaders' abilities to work closely with people from around the world in situations that are only minimally defined by a hierarchical structure. Successfully using power with skills means being able to work effectively in the geographically dispersed and flattened organizational structures and project teams inherent to twenty-first century business dynamics. Power with skills include communicating, negotiating, team building, mentoring, and leading across multiple cultures. A series of Forum activities focused on enhancing participants' skills at working with colleagues from around the world, the most central of which were daily meetings of the global teams. Other opportunities to enhance cross-cultural power with skills included: an experiential Perfect Square 


\begin{tabular}{|c|c|c|c|}
\hline Forum Activities & $\begin{array}{c}\text { Leadership } \\
\text { Development }\end{array}$ & $\begin{array}{l}\text { Team } \\
\text { Building }\end{array}$ & $\begin{array}{c}\text { Organizational } \\
\text { Development }\end{array}$ \\
\hline $\begin{array}{l}\text { Saturday } \\
\text { Half-day Facilitator Training }\end{array}$ & $X$ & & \\
\hline $\begin{array}{l}\text { Sunday } \\
\text { Pre-Forum Activities } \\
\text { Reception \& Opening Dinner, with } \\
\text { - Board Members \& corporate directors as guests } \\
\text { - Seating in global teams } \\
\text { - CEO welcoming address }\end{array}$ & & $\begin{array}{l}X \\
X\end{array}$ & $\begin{array}{l}X \\
X\end{array}$ \\
\hline $\begin{array}{l}\text { Daily } \\
\text { Daily time for personal reflection, power within, and } \\
\text { leadership role models } \\
\text { - Early morning \& late afternoon healthy breaks } \\
\text { - Quotes from the world's women leaders } \\
\text { - Inner voice chime } \\
\text { - Global Wisdom and Insight Journal } \\
\text { - Evening hospitality suite }\end{array}$ & $\begin{array}{l}X \\
X \\
X \\
X\end{array}$ & $X$ & $X$ \\
\hline $\begin{array}{l}\text { Monday } \\
\text { a.m. Who are we: Building the Leadership Network } \\
\text { CEO opening keynote address } \\
\text { Retaining Global Talent } \\
\text { Leadership and Power } \\
\text { Lunch. How well do you know your international colleagues? } \\
\text { p.m. Group photo } \\
\text { Building Global Teams: The Perfect Square } \\
\text { Leadership \& Vision: The Power To } \\
\text { Perceiving a Global Reality } \\
\text { Is it true: Reality \& Perception (Survey Feedback) }\end{array}$ & $\begin{array}{l}X \\
X \\
X \\
X \\
X\end{array}$ & $\begin{array}{l}X \\
X \\
X \\
X\end{array}$ & $\begin{array}{l}X \\
X \\
X \\
\\
X \\
\\
X \\
X\end{array}$ \\
\hline $\begin{array}{l}\text { Tuesday } \\
\text { a.m. Workforce Inclusion: Talent as a competitive asset } \\
\text { Competetive Frontiers: Women Managers in a Global } \\
\text { Economy (International assignments) } \\
\text { Lunch. Ethnic Lunch } \\
\text { p.m. Herstory: The Roots of Women's Global Leadership } \\
\text { Assessing Leadership Excellence } \\
\text { Women and Business Opportunities: The Bottom Line }\end{array}$ & $\begin{array}{l}X \\
X \\
X \\
X\end{array}$ & $X$ & $\begin{array}{l}X \\
X \\
X\end{array}$ \\
\hline $\begin{array}{l}\text { Wednesday } \\
\text { a.m. Global Leaders: A Dialogue with Future History } \\
\text { Men Mentoring Women: Our Best Wisdom } \\
\text { Women Mentoring Women: Our Best Wisdom } \\
\text { Lunch. Cross-Cultural Coaching } \\
\text { p.m. Cross-Cultural Negotiating \& Coaching } \\
\text { Organizational Change and Development } \\
\text { Team Preparation for CEO Presentation }\end{array}$ & $\begin{array}{l}X \\
X \\
X \\
X \\
X \\
X\end{array}$ & $X$ & $\begin{array}{l}X \\
X \\
X \\
X \\
X\end{array}$ \\
\hline $\begin{array}{l}\text { Thursday } \\
\text { a.m. The Future: The Global Women's Leadership Newtwork Acts } \\
\text { Recommendations presented to CEO \& senior executives } \\
\text { Closing Reflection \& Feedback in Global Teams } \\
\text { Response from CEO } \\
\text { Lunch. Closing lunch celebration with CEOs \& executives }\end{array}$ & $\begin{array}{l}X \\
X\end{array}$ & $\begin{array}{l}X \\
X \\
X\end{array}$ & $\begin{array}{l}X \\
X \\
X\end{array}$ \\
\hline
\end{tabular}


A second explicit goal of the CEO was to create a network among the company's women leaders to facilitate their global effectiveness. global team building exercise, a cross-cultural negotiating session in which participants could coach their colleagues on effective approaches to working with people around the world, two mentoring panels, and a closing session in which each woman could receive cross-cultural feedback on her overall effectiveness from Asian, European, Middle Eastern, and North and South American colleagues.

Power within. Power within recognizes that a primary source of global leaders' power comes from outside their organizational role. Power within derives from leaders' deeply held personal and spiritual values and beliefs. Forum sessions were designed to give participants time to clarify the relationship between their career aspiration, their leadership approaches, and their most deeply held values and convictions. For example, each day time was set aside for participants to reflect on their reactions and feelings and to record them in a personal Global Wisdom and Insight Journal. Early morning and late afternoon time, entitled Healthy Breaks, was set aside for personal exercise and/or additional private reflection. In another power within session, entitled Herstory: The Roots of Global Leadership, participants clarified the deepest sources of their values and leadership role models by identifying women whose leadership they wished to emulate. The women discussed how they planned to incorporate their role models' approaches into their own leadership goals and style. The Herstory session allowed participants to examine more closely the ways in which women have exercised power both currently and in the past. ${ }^{9}$

Increasing Effectiveness: Developing a Network of Women Leaders

A second explicit goal of the CEO was to create a network among the company's women leaders to facilitate their global effectiveness. Bringing together 55 of the company's most senior and highest potential women at the Women's Global Leadership Forum was the first step in achieving this goal. Most Forum activities were designed to strengthen the network, initially by allowing the women to get to know each other, including learning about each other's national, regional, and cultural backgrounds. For example, on the first morn- ing of the Forum-in a session entitled Who Are We? - each participant introduced herself by describing either one way in which being a woman had helped her professionally or one funny professional experience that had happened to her because she is a woman. Such stories allowed participants to more fully understand the professional impact of being a woman and to more clearly appreciate the worldwide commonality among women's positive professional experiences. While each participant recounted her personal story, a picture of her, with her name, title, country, and cultural affiliation, was projected, thus ensuring that all participants would begin to recognize their fellow network members.

Using symbolism to further enhance recognition of the cultural diversity within the company-and, therefore, within the network-a country flag representing each woman's nationality was flown next to her name tent. Centerpieces mixing the national flowers from all participants' countries further symbolized the importance and uniqueness of women coming together from around the world to form a leadership network.

Among other network building activities, a How well do you know your international colleagues? lunch session was held that paired women from various parts of the world in conversation about themselves, their countries, and leadership styles. The goal was not simply to increase understanding of each other's countries, but rather to begin to create cultural synergy - that is, to begin to combine unique cultural perspectives for the benefit of the individual women, the network, the company, and society (Adler, 1997c).

Developing the Organization: Retaining and Developing Leadership Talent

Two of the CEO's core goals for the Forum focused on organizational development:

- Increasing Bestfoods' global competitiveness

- Enhancing Bestfoods' support for the career advancement and success of an increasing number of highly talented and senior women 
Numerous aspects of the Forum were designed to achieve these two organizational goals. First, rather than having the women meet only among themselves, the CEO invited all corporate officers and members of the board to participate in various aspects of the Forum throughout the 4 1/2 days. The CEO himself joined the Forum for Sunday evening's opening reception and dinner, Monday morning's participant introductions and welcoming keynote address, and Thursday's presentation and discussion of recommendations. In total, this represents a highly significant commitment of senior executive time.

To immediately focus attention on organizational goals, Brody presented the survey results on Monday morning, followed by global team meetings to begin developing recommendations to the company for retaining talented women from around the world. The global teams identified recommendations for increasing women's chances of staying at the company and not going to the competition, succeeding at the company, and being recognized for their professional accomplishments.

Following Tuesday's lecture on Competitive Frontiers: Women Managers in a Global Economy, which documented the experience of companies worldwide in sending women abroad on international assignments, participants identified the conditions needed for Bestfoods to successfully send both single and married woman - either with or without children-abroad for both shorter and longer term assignment (Adler, 1994). The women recommended the types of conditions and benefits the company would need to provide, as well as the kinds of preparation each woman and her family would need to undertake. This discussion was particularly important as most companies' expatriate philosophies, policies, and benefits packages were designed for married men with stay-at-home wives - not for the type of women represented at the Forum (Adler, 1997c; Osland, 1995).

To highlight the increasing number of women leading global companies and countries and their unique career paths, a lecture on Global Leadership: A Dialogue with Future History was planned for Wednesday (Adler, 1997a). The lecture and ensuing discussion were designed to give participants access to a wide range of female role models and the career paths successful women use to become leaders in global organizationscareer paths that rarely replicate those of the men who have traditionally led the world's major corporations.

\section{The Forum in Retrospect}

When the Forum ended, everyone agreed that it had been a success. CEO Dick Shoemate said it had exceeded his already high expectations. He candidly remarked that the caliber of the women, their thoughtful and sound recommendations, and their outstanding final presentations rivaled the quality of other senior executive groups with whom he had worked.

Participants echoed the same sentiment. Reactions included one woman who exclaimed, "I had no idea that there were so many talented and outstanding women in this company!" Another senior woman who leads a $\$ 400$ million business addressed the CEO at the closing session, saying "At first I was hesitant about coming to a company forum just for women. Yet this has been a wonderful experience. Mr. Shoemate, this is a group of outstanding business colleagues, each of whom just happens to be a woman."

Brody and the consultants similarly concluded that the program had been highly successful. Nevertheless, an analysis of the 4 1/2-day global Forum reveals the unique challenges of bringing together women from around the world to simultaneously address both major organizational change issues and individual leadership development agendas. Given the importance the women attached to the CEO's challenge to change the organization, their priority was to take advantage of the unique opportunity the Forum offered to present high-quality recommendations to the senior executives. The original Forum agenda was therefore altered to reflect the participants' immediate needs to formulate suggestions for changing the organization. Perhaps the lesson to be learned regarding first meetings of this sort is that participants may initially view sessions designed for individual development not only as difficult, but also as superfluous or suspect (as taking them

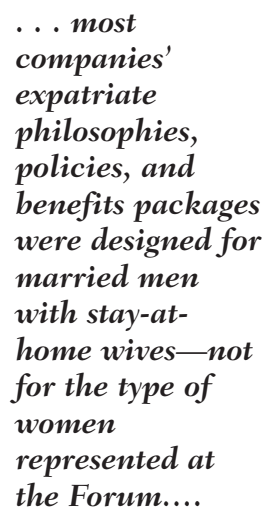




Another cross-
cultural
difference the
group
experienced
relates to what
anthropologists
call the source of
truth ....

Another crosscultural difference the relates to what call the source of truth .... away from opportunities to change the organization). Care should be taken in future meetings to ensure that individual and organizational goals remain complementary.

From the beginning of the Forum, it became apparent that women from throughout Bestfoods have diverse backgrounds and career experiences. Participants learned to accept that differences in their age, tenure, rank, and geographical region meant that the group did not need to come to a consensus on a uniform "women's" perspective or position. Some senior-level women who had begun their professional life in a different social climate and who saw their careers as having plateaued, albeit at a very senior level, held very different attitudes and objectives from those of some younger women whom the company had more recently identified as fast trackers. Just as one would not expect a group of male executives to have identical experiences and opinions, there is seldom a uniform "women's viewpoint", and neither companies nor women should expect one. As highlighted in the Forum, helping people appreciate different realities is a crucial step in allowing them to move beyond the need to come to a consensus on either "the state of women" or attributions about why women do and do not make it to the top of organizations.

Over the course of the Forum, varied cross-cultural communication and behavioral styles influenced the group dynamics and learning climate. For example, many North American participants preferred to take a more inductive approach to resolving issues and making recommendations-that is, they wanted to start with the specifics of their own and other's personal experience, ultimately arriving at overall generalizations. Women from many other cultures preferred to begin with a general theory and concepts and then work down toward the specifics of their own lives - a more deductive approach. Both approaches ultimately arrive at an integration of the general and specific; the process for arriving at integration, however, is culturally defined, opposite, and can be difficult to bridge.

Another cross-cultural difference the group experienced relates to what anthropologists call the source of truth-how a group seeks the "right" answer, or in the case of the
Forum, the "right" recommendation. Is truth believed to come primarily from scientific research, legal precedent, the opinion of experts, tradition, personal experience, or trial and error? The range of reactions to the announcement that the agenda would be changed to allow more time for participants to work in teams on organization development issues reflects this cultural difference. Some of the Asian and Latin American women felt disappointed since the agenda change meant less time to hear formal presentations by experts. While clearly indicative of their more deductive approach, the Asians and Latin Americans' higher respect for expert input may also have reflected the greater value they place on authority, position, and hierarchical status-what the anthropologists and cross-cultural management scholars refer to as high power distance (Hofstede, 1980a; 1980b; Hofstede \& Bond, 1988). By contrast, most of the Americans welcomed the agenda change and expressed their belief that this would give them more time to do what was important: develop recommendations based on their own experience.

Some Asian, European, and Latin American participants found many of the North American women a bit too blunt and directtaking charge and attempting to solve problems too quickly and without sufficient consultation or reflection. In contrast, some North Americans occasionally expressed frustration with the deference and respect that women from other cultures more frequently showed to senior management. At times, the Americans tended to interpret the reticence of some of their cross-cultural colleagues to challenge the hierarchy as the other cultures' implicit acceptance of women's somewhat lesser stature, knowledge, and opinions. The formality and reserved nature of many women from outside of the United States, as well as the strong emphasis such cultures place on relationship building and putting the needs of the group ahead of any one individual's opinion or needs (including one's own), contrasted with the behavior of the highly verbal and more individualistic Americans. Fortunately, participants were alerted to potential cross-cultural differences at the beginning of the Forum. Thus, the personal discovery of 
different cultural and value-based norms regarding "appropriate" behavior and manners more often became a source of humor than frustration.

Throughout the Forum, there was a high level of energy. The team-building and networking aspect worked well and resulted in numerous business discussions and sharing of ideas. There was a strong sense of teamwork during the preparation of recommendations and a palpable sense of support and pride in the presenters, who did an excellent job. The women committed to forming a global network to stay connected, electronically and in person, following the Forum.

\section{Organizational Change: It Doesn't Have to Take That Long}

The women's recommendations fell into three major categories:

1. Career Development_enhancing career opportunities

2. Diversity - increasing women's representation in senior and high level positions

3. Work/Life Balance-enabling women to perform to their highest capabilities

After the women presented their recommendations, they returned to their teams for closure and celebration. During this time, the CEO and other senior executives on the Corporate Strategy and Diversity Advisory Councils met with Brody and the consultants to craft an initial real-time response to the women's recommendations. The CEO separated the recommendations into three response categories:

- Current company initiatives-activities already underway, whose progress needed to accelerate and be communicated better

- New corporate-wide recommendations - with potentially high impact

- New "local" recommendationsbest addressed within specific countries, regions, or divisions

\section{Current Company Initiatives}

Recommendations in the first category included such activities as equitable job-posting, performance enhancement, and development planning for both women and men. As the company was already involved in these initiatives, the CEO immediately committed to an accelerated effort and/or better communication of the results being achieved.

\section{New Corporate-Wide Recommendations}

The women proposed the following corporatewide recommendations:

- Communicate to all global managers the CEO's expectation to make significant progress on retaining and developing high performing women

- Rapidly share learnings from the survey and Forum with all divisions

- Establish senior management accountability (for retaining and developing high performing women) by linking goal attainment to the annual incentive program and announcing this new accountability at the next global executive meeting

- Create flexible international assignments of shorter duration as an alternative to traditional expatriate assignments

- Increase women's participation in high visibility assignments and taskforces-especially those with a global focus

- Provide flexibility in defining the "work-day" and "work-place" to enable managers to avoid the current "all or nothing" ("work or stay home") choice when attempting to balance organizational demands and extraordinary private life demands

- Expand membership on the previously all-North American Diversity Advisory Council to include participants from outside of the United States

While still at the Forum, Dick Shoemate agreed to put the entire set of new corporate-wide recommendations on 
In September, less than two months after the Forum, the Corporate Strategy Council met and approved all new corporate-wide recommendations as well as approving two additional actions beyond those recommended by the women. the agenda at the next Corporate Strategy Council (CSC) meeting.

In September, less than two months after the Forum, the Corporate Strategy Council met and approved all new corporate-wide recommendations as well as approving two additional actions beyond those recommended by the women. Among these additional commitments, they agreed to take responsibility for oversight of the company's global diversity strategy, thus inextricably linking the company's business and diversity strategies. To further ensure effective company-wide implementation and to address many of the regional and country-level diversity issues, CSC members (as division presidents) committed to replicating the corporate diversity council architecture in each of their respective businesses, as well those of the unit presidents reporting to them. In this way, the CSC improved upon the Forum recommendation of simply adding international representatives to the preexisting U.S.-based council; they believed local councils would have a greater impact in speed, scope, and scale.

The CSC also approved an aggressive company-wide strategy for consistently communicating the results and learnings from the Forum, including corporate objectives and commitments for advancing and retaining women, to all organizational units, including corporate headquarters, each division, and all country operations. To accelerate the process, Brody summarized the Forum results in presentation format, thus providing women's network members with the outlines and graphics they needed to effectively communicate the Forum results and new corporate commitments to their regions and divisions. The ensuing series of presentations provided consistent feedback to managers worldwide. At the October WorldTeam Meeting - the biannual meeting of the company's 145 most senior executives, Brody formally presented the Forum results and the next steps that Bestfoods would be taking. She announced a new Bestfoods' strategic performance goal: to increase the number of high potential women from 15 percent to 25 percent by the year 2005. Following the WorldTeam Meeting, things moved very quickly.
New "Local" Initiatives

Division councils were announced with many Forum participants serving on the various councils to help guide, influence, and implement their division's diversity strategy. In the larger countries, management held country-level meetings to further communicate corporate objectives, Forum results, division strategies, and reasons for forming division-level councils, as well as to formulate their own local initiatives.

In Latin America, for example, not only did Argentina, Brazil, Colombia, and Mexico form country-level councils, but each country also started benchmarking itself against the diversity initiatives of other multinationals operating in the area. They discovered that unlike Bestfoods' Latin American affiliates, almost none of these competitors had local diversity strategies or used quantitative measures to establish country-level objectives regarding hiring and retaining women and assessing their achievement. These findings alone foretold a distinct advantage for Bestfoods' Latin American affiliates in recruiting early career professionals, especially since more than thirty percent of their new recruits typically are women.

Also in October, under the leadership of their diversity council chairman and two Forum participants, Argentina mirrored the corporate model and conducted a one-day Argentine Women's Forum for 24 women managers who either report directly to the general manager or to one of his direct reports. Mexico soon followed.

With the division president's support and visible commitment, Europe's newly formed diversity council crafted a regional strategy for increasing the number of women retained by the company and for enhancing their development opportunities. Council representatives attended a two-day senior executive program on Managing Inclusion. (Bestfoods' top 300 North American managers are also attending the same program.) The European Council is currently considering offering a modified version of this program for its senior team.

In the large businesses in the United States, diversity councils and implementation teams are forming at various organizational levels. In addition, corporate headquarters and Asia are actively using their executive education programs and senior level positions to improve their retention and 
development of high performing women and to support the Global Women's Network.

\section{Using the Global Women's Network}

Among themselves, the women quickly began using the Global Women's Network developed at the Forum. They shared their re-entry stories-describing positive experiences as well as stories of a negative backlash from some men and women who had not been at the Forum. The women also began taking advantage of the network for coaching, professional support, and notifying each other of career opportunities. They are currently and regularly using the Network to create and to exchange career, organization development, and business strategies.

\section{The Meaning of Success}

As poet Emily Dickinson (1951) poignantly suggests to women:
We never know how high we are/Till we are asked to rise/And then if we are true to plan/ Our statures touch the skies

In convening the Women's Global Leadership Forum, CEO, Dick Shoemate, invited the most senior and highest-potential women in his organization to rise. The process of the Forum and the outcomes that are currently unfolding are proving that neither the company nor the women themselves knew how high they could, should, or would collectively rise. Bestfoods' future competitive success as a company depends on the leadership of both women and men-on the contribution of both feminine and masculine perspectives. The Women's Global Leadership Forum was an experiment in amplifying women's voices. Not only the success of Bestfoods, but the success of twenty-first century society depends on the same variety of voices being amplified and heard.

Nancy J. Adler is a Professor at McGill University in Montreal, Canada. Dr. Adler consults with global companies and government organizations on projects in Asia, Europe, North and South America, and the Middle East. She conducts research on strategic international human resource management, global leadership, and global women leaders. She has authored more than 100 articles and produced the film, A Portable Life. Her books include International Dimensions of Organizational Behavior (with over 100,000 copies in print), Women in Management Worldwide, and Competitive Frontiers: Women Managers in a Global Economy. Professor Adler is a Fellow of both the Academy of Management and the Academy of International Business.

Laura W. Brody is currently the Director of Diversity and Development for Bestfoods. Over the past three years she has been responsible for a variety of workforce diversity initiatives including: Cultural Connections - an employee driven education and awareness program, Sponsoring Our Success-a peer coaching and mentoring program for new hires, The Women's Global Leadership Forum-a worldwide career development and leadership program, as well as serving as the facilitator for the Diversity Advisory Council, which is chaired by the CEO.

Joyce S. OsLand is associate professor of organizational behavior at the University of Portland, Oregon. She lived and worked overseas in seven countries, primarily in West Africa and Latin America for 14 years, working as a manager, researcher, consultant, and professor. Dr. Osland's current research and consulting focus includes expatriates, cultural sense making, Latin American management, and global leadership. She is the author of The Adventure of Working Abroad: Hero Tales from the Global Frontier (JosseyBass, 1995) and co-author of Organizational Behavior: An Experiential Approach and The Organizational Behavior Reader (Prentice Hall, 2000). 


\section{REFERENCES}

Adler, N.J. (1999a). Global entrepreneurs: Women, myths, and history. Global Focus, 11(4), 125134.

Adler, N.J. (1999b). Global leaders: Women of influence. In Gary Powell (Ed.), Handbook of gender in organizations. Thousand Oaks, CA: Sage, 239261.

Adler, N.J. (1999c). Twenty-First century leadership: Reality beyond the myths. In Richard Wright (volume ed.), Research in global strategic management, Vol. 7. International entrepreneurship: Globalization of emerging business (pp. 173190). Greenwich, CT: JAI Press.

Adler, N.J. (1998a). Did you hear? Global leadership in charity's world. Journal of Management Inquiry, 7(2), 21-33.

Adler, N.J. (1998b). Societal leadership: The wisdom of peace. In Suresh Srivastva (Ed.), Executive wisdom and organizational change (pp. 243-337). San Francisco, CA: Jossey-Bass.

Adler, N.J. (1997a). Global leaders: A dialogue with future history. International Management, 1(2), 21-33.

Adler, N.J. (1997b). Global leadership: Women leaders. Management International Review, 37 (Special Issue 1), 135-143.

Adler, N.J. (1997c). International dimensions of organizational behavior, (3rd ed.). Cincinnati, $\mathrm{OH}$ : South Western Press.

Adler, N.J. (1996). Global women political leaders: An invisible history, an increasingly important future. Leadership Quarterly, 7(1), 133-161.

Adler, N.J. (1994). Competitive frontiers: Women managing across borders. In Nancy J. Adler \& Dafna N. Izraeli (Eds.), Competitive frontiers: Women managers in a global economy (pp. 2240). Cambridge, MA: Blackwell.

Bartlett, C.A., \& Ghoshal, S. (1989). Managing across borders: The transnational solultion. Boston, MA: Harvard Business School Press.

Dickinson, E. (1951). We never know how high we are. In Thomas H. Johnson (Ed.), The Poems of Emily Dickinson. Cambridge, MA: Belknap Press of Harvard University Press.

Dorfman, P.W. (1996). International and cross-cultural leadership. In B.J. Punnett \& Oded Shenkar (Eds.), Handbook for international management research. Cambridge, MA: Blackwell, 267-349.

Dwyer, P., Johnston, M., \& Lowry (1996). Europe's corporate women. Business Week, April 15, 4042.

Fisher, A.B. (1992). When will women get to the top? Fortune, September 21, 44-56.
Gardner, H. (1995). Leading minds: An anatomy of leadership. New York: Basic Books.

Hambrick, D.C., Korn, L.B,. Frederickson, J.W., \& Ferry, R.M. (1989). 21 st Century report: reinventing the CEO. New York: Korn/Ferry and Columbia University's Graduate School of Business, 1-94.

Hamel, G., \& Prahalad, C.K., (1986). Do you really have a global strategy? Harvard Business Review, July-August, 138-148.

Hill, C.W.L. (1998). International business: Competing in the global marketplace (2nd ed.). Whitney, New York: Irwin/McGraw Hill.

Himelstein, L. (1996). Shatterproof glass ceiling. Business Week, October 28th, 55.

Hofstede, G. (1980a). Culture's consequences: International differences in work-related values. Beverly Hills, CA: Sage.

Hofstede, G. (1980b). Motivation, leadership and organization: Do American theories apply abroad? Organizational Dynamics, 9(1), 4263.

Hofstede, G., \& Bond, M. (1988). The confucious connection: From cultural roots to economic growth. Organizational Dynamics, 16(4), 4-21.

International Labor Office. (1997). Breaking through the glass ceiling: Women in management. Geneva: International Labor Office.

Kanter, R.M. (1994). Comments on Nancy A. Nichols' Reach for the top: Women and the changing facts of work life. Boston, MA: Harvard Business School Press, as cited in the book review by John R. Hook in The Academy of Management Executive, 8(2), 87-89.

Mitroff, I. (1987). Business not as usual. San Francisco, CA: Jossey-Bass.

Osland, J.S. (1995). The adventure of working abroad: Hero tales from the global frontier. San Francisco, CA: Jossey-Bass.

Osland, J.S., Snyder, M.M., \& Hunter, L. (1998). A comparative study of managerial styles among female executives in Nicaragua and Costa Rica. International Studies of Management and Organization, 28(2), 54-73.

Ragins, B.R. (Townsend, Bickley, \& Mattis, Mattis), (1998). Gender gap in the executive suite: CEOs and female executives report on breaking the glass ceiling. Academy of Management Executive, 12(1), 28-42.

Roberts, C. (1998). We are our mothers' daughters. New York: William Morrow and Company.

Wellington, S.W. (1996). Women in corporate leadership: Progress and prospects. New York: Catalyst. 


\section{ENDNOTES}

1. For a more indepth discussion of women political leaders, see Adler (1996), (1997a), (1998a), and (1998b).

2. For a more indepth discussion of global women business leaders, see Adler (1997a), (1997b), (1998b), (1999a), and (1999b).

3. CEO's statement is Bestfoods' World Team Management Development Philosophy.

4. The Corporate Strategy Council is composed of the six most senior corporate officers, who are responsible for the four geographic divisions, the baking business, and the corporate staff. All six senior corporate officers are men.

5. The survey was loosely based on Catalyst's report (Wellington, 1996). It should be noted that men may believe that such mentor relationships need to be more formal, and at the minimum, organizationally sanctioned.

6. Forty-four percent of women, and yet only 4.8 percent of men, believed that developing a style that men are comfortable with was critical to women's career advancement.

7. Thirty-six percent of women, and yet only 19 percent of men, believed that having a mentor was important for women's career success. It should be noted that men may believe that such "mentorship" happens naturally and informally; whereas women-primarily due to their scarcity in senior management-may believe that such mentor relationships need to be more formal, and, at the minimum, organizationally sanctioned.

8. Whereas 60 women were invited, only 55 were able to attend on the dates set for the Forum. Given the strict selection process, substitutes were not invited.

9. For a discussion of the roots of women's power and the fact that this generation of women does not have to invent all aspects of leadership, even if they are firsts, see Cokie Roberts (1998). 
Copyright of Human Resource Management is the property of John Wiley \& Sons, Inc. / Business. The copyright in an individual article may be maintained by the author in certain cases. Content may not be copied or emailed to multiple sites or posted to a listserv without the copyright holder's express written permission. However, users may print, download, or email articles for individual use. 